\title{
PENGEMBANGAN INSTRUMEN PENILAIAN AUTENTIK MELALUI TUGAS PROYEK PADA MATERI STATISTIKA SMP
}

\author{
Rosita Dwi Ferdiani, Tatik Retno Murniasih \\ Dosen Pendidikan Matematika Universitas Kanjuruan Malang \\ Rositazahra22@gmail.com \\ Tretnom@unikama.ac.id
}

\begin{abstract}
Abstrak: Penelitian ini bertujuan untuk mengembangkan instrumen penilaian autentik berbasis tugas proyek pada materi statistika SMP. Jenis Penelitian ini adalah pengembangan dengan model pengembangan Borg \& Gall, yang dibatasi pada beberapa tahap saja. Tahap-tahap tersebut meliputi: tahap pengumpulan informasi, tahap perencanaan, tahap pengembangan produk; dan tahap validasi dan ujicoba. Pada tahap pengumpulan informasi dimulai dengan penentuan materi dan analisis kebutuhan yang akan digunakan dalam pengembangan produk. Pada tahap perencanaan ini terdiri dari pembuatan kisi-kisi instrumen penelitian yang menjadi kriteria penilaian autentik melalui tugas proyek. Sedangkan pada tahap pengembangan, terdapat beberapa langkah - langkah pengerjaan yaitu: membuat rancangan pembelajaran berbasis tugas proyek, membuat soal untuk tugas proyek yang berhubungan dengan materi statistika SMP kelas IX, membuat rubrik penilaian tugas proyek. Tahap validasi dilakukan oleh ahli pembelajaran dan ahli materi matematika. Untuk tahap ujicoba dilakukan pada siswa kelas IX SMP Al Inayah Purwosari, Pasuruan.

Hasil validasi ahli pembelajaran menunjukkan hasil jumlah skor sebesar 78 dengan persentase $78 \%$, dan rerata skor sebesar 3,95 dengan kategori "baik". Sedangkan Hasil validasi ahli materi menunjukkan hasil jumlah skor sebesar 85 dengan persentase $85 \%$, dan rerata skor sebesar 4,25 dengan kategori "baik". Berdasarkan hasil validasi dari kedua ahli yaitu ahli materi dan ahli pembelajaran menunjukkan kategori baik, sehingga produk instrumen penilaian autentik berbasis tugas proyek layak untuk digunakan dalam pembelajaran matematika pada materi statistika SMP.
\end{abstract}

Kata Kunci: Penilaian, autentik, tugas proyek

Abstrak: This study aims to develop an authentic assessment instrument based on the project task in statistics for SMP subject. This type of this research is the development using the Borg \& Gall development model, which is limited to a few stages. The stages include: information gathering phase, the planning stage, the stage of product development; and the validation and testing. The information-gathering phase begins with the determination of material and analysis of requirements to be used in product development. The planning stage consists of the creating lattice research instrument that becomes the criterion of authentic assessment through project task. While at the stage of development, there are several steps, those are: making course outline with projects task-based, making questions for project task related with statistics material for SMP grade IX, creating project tasks assessment rubric. The validation phase is done by the experts of learning and mathematics subject matter. The pilot phase carried out in grade IX SMP Al Inayah Purwosari, Pasuruan. The results of learning expert validation show the total score is 78 with a percentage of $78 \%$, and the mean score is 3.95 with "good" category. While the results of mathematics subject matter expert validation show the total score is 85 with a percentage of $85 \%$, and the mean score of 4.25 with "good" category. The validation results of the two experts, they are mathematics subject matter experts and learning experts show good category, so the authentic assessment instrument product based on the project task is feasible to be used in mathematics learning in statistical material for SMP.

Keywords: Assessment, authentic, project tasks

\section{PENDAHULUAN}

Pada era globalisasi sekarang ini, tantangan ini, maka diperlukan sumber daya Indonesia memasuki era perdagangan bebas manusia yang berkualitas. Peningkatan kualitas kawasan Asia Tenggara. Untuk menghadapi sumber daya manusia seiring dengan 
peningkatan kualitas pendidikan. Kualitas pendidikan tergantung pada kualitas pembelajaran dan penentuan standart penilaian.

Pelaksanaan penilaian merupakan bagian terpenting dari pembelajaran di kelas. Dengan adanya penilaian, guru dapat mengetahui kemampuan siswa dalam memahami materi pelajaran, sehingga guru dapat memperbaiki pembelajarannya. Hal ini sependapat dengan Hamzah (2012: 2), assessment dapat diartikan sebagai proses untuk mendapatkan informasi dalam bentuk apapun yang dapat digunakan untuk dasar pengambilan keputusan tentang siswa, baik yang menyangkut kurikulum, program pembelajaran, iklim sekolah maupun kebijakan-kebijakan sekolah. Assessment secara sederhana dapat diartikan sebagai proses pengukuran dan non pengukuran untuk memperoleh data karakteristik siswa dengan aturan tertentu. Selain itu penilaian dapat dijadikan sebagai bahan evaluasi bagi guru dalam meningkatkan kualitas pembelajaran dengan cara memperbaiki rencana pelaksanaan pembelajarannya. Hal ini sesuai dengan pernyataan Havnes (2008: 11) yaitu ketika guru menilai pekerjaan serta kemajuan siswa, guru juga dapat melihat seberapa sukses dalam mengajar.

Pelaksanaan penilaian di sekolah sekolah khususnya di tingkat SMP hanya berorentasi pada penilaian akhir sehingga kurang memperhatikan aspek afektif, kognitif, dan spikomotorik dari dalam diri siswa. Tentunya hal ini bertentangan dengan salah satu prinsip penilaian Permendiknas Nomor 20 tahun 2007 yang menyatakan bahwa penilaian adalah proses menyeluruh dan berkesinambungan, berarti penilaian harus mencakup semua aspek kompetensi dengan menggunakan berbagai teknik penilaian yang sesuai, untuk memantau perkembangan siswa. Hal ini terlihat dari pelaksanaan ujian akhir semester atau ujian akhir sekolah. Guru seringkali menjadikan penilaian hasil ujian akhir semester atau ujian akhir sekolah sebagai dasar dalam mengambil keputusan tentang prestasi atau kemampuan siswa. Sehingga apabila siswa mengalami penurunan nilai pada saat ujian akhir semester atau ujian akhir sekolah, maka siswa tersebut dinyatakan tidak naik kelas ataupun tidak lulus sekolah.

Selama ini, soal - soal ujian akhir semester ataupun ujian akhir sekolah khususnya pada mata pelajaran matematika tingkat SMP, hanya berupa pilihan ganda ataupun soal uraian singkat. Sehingga siswa seakan - akan dihadapkan kepada persoalan yang sudah ditentukan jawabannya. Hal ini tentunya kurang dapat menggali kemampuan siswa baik dari segi afektif, kognitif dan spikomotorik. Akibatnya siswa kurang mempunyai sikap yang positif dalam memanfaatkan dan mengaplikasikan ilmu pengetahuan yang dimiliki terhadap lingkungan sekitar.

Tugas - tugas rumah yang diberikan kepada siswa pun berisi soal uraian singkat, dan kurang menggali kemampuan siswa dalam menganalisi permasalahan ataupun kurang menampilkan ide kreatif siswa. Guru jarang memberikan tugas proyek yang berbasis pada permasalahan sehari - hari yang dikaitkan dengan salah satu materi pelajaran yang dipelajari di kelas. Akibatnya siswa kurang tertantang ide kreatifnya dalam menyelesaikan tugasnya.

Berdasarkan observasi awal yang dilakukan di kelas IX SMP Al Inayah Purwosari Pasuruan, pemberian tugas yang diberikan kepada siswa hanya sebatas tugas rumah. Siswa jarang diberikan tugas proyek yang berdasarkan permasalahan sehari- hari. Akibatnya siswa kurang dapat mengkaitkan hubungan antar konsep dalam matematika dengan permasalahan sehari - hari. Hal ini terlihat pada materi statistika. Materi statistika mempunyai cakupan materi yang luas, dimana siswa dilatih untuk 
mengumpulkan data, mengasosiakan data, memodelkan kedalam sebuah diagram, serta menerapkan operasi perhitungan untuk menentukan rata - rata data. Siswa masih kebingungan dalam mencari rata - rata, quartil, dan modus dari suatu data yang jumlahnya banyak. Siswa belum terbiasa menerapkan operasi perhitungan data dengan jumlahnya banyak. Hal ini terbukti dari hasil tes awal yang dilakukan peneliti untuk materi ini, siswa yang mendapat nilai dibawah 60 mencapai $62 \%$ dengan rata - rata kelas 54,7.

Untuk mengatasi permasalahan tersebut diperlukan perubahaan penilaian guru dalam menilai kemampuan siswa sehingga pembelajaran akan lebih bermakna. Penilaian autentik melalui tugas proyek merupakan salah satu solusi dari permasalahan tersebut. Hal ini sesuai yang dituliskan oleh Mueller (2012), bahwa penilaian autentik adalah penilaian dimana siswa diminta untuk melakukan tugastugas yang sesuai dengan permasalahan sehari hari yang menunjukkan makna dari pengetahuan dan keterampilan. Pernyataan tersebut juga sejalan dengan Arikunto (2008: 23) yang menyatakan penilaian otentik adalah suatu penilaian belajar yang merujuk pada situasi atau konteks "dunia nyata", yang memerlukan berbagai macam pendekatan untuk memecahkan masalah yang memberikan kemungkinan bahwa satu masalah bisa mempunyai lebih dari satu macam pemecahan. Dengan kata lain, assessment otentik memonitor dan mengukur kemampuan siswa dalam bermacam-macam kemungkinan pemecahan masalah yang dihadapi dalam situasi atau konteks dunia nyata.

Pemberian tugas proyek kepada siswa merupakan salah satu cara untuk menilai siswa dalam memecahkan masalah dalam kehidupan nyata serta mengembang-kan dan meningkatkan kemampuan dan ketrampilan siswa. Hal ini sejalan dengan pendapat Burton (2011: 21) yang menyatakan bahwa penilaian autentik adalah penilaian yang menghubungkan pengetahuan dengan praktik di lapangan. Teknik penilaian autentik antara lain adalah penilaian proyek penilaian, keterampilan, penilaian produk, penilaian portofolio, penilaian diri, penilaian teman sejawat, ujian tertulis, dan observasi.

Penilaian autentik tidak mengarah-kan siswa untuk mengerjakan soal - soal uraian ataupun menghafal suatu materi pelajaran, tetapi lebih kepada riset atau percobaan, uji literatur, penugasan proyek atau penyelesaian soal - soal aplikasi yang sesuai dengan kehidupan nyata. Sehingga guru mengetahui setiap tahapan perkembangan kemampuan siswa.

\section{METODE PENELITIAN}

Penelitian pengembangan ini mengacu pada model pengembangan dan Borg \& Gall, yang dibatasi pada beberapa tahap saja. Tahaptahap tersebut meliputi: a) tahap pengumpulan informasi; b) tahap perencaan; c) tahap pengembangan produk; dan d) tahap validasi dan ujicoba. Dalam penelitian ini produk yang dimaksud adalah instrumen penilaian autentik melalui tugas proyek pada materi statistika di kelas IX di SMP Al Inayah Purwosari Kabupaten Pasuruan.

Penelitian dilaksanakan di SMP Al Inayah Purwosari Kabupaten Pasuruan. Penggunaan sampel penelitian terdapat pada tahapan validasi dan uji coba instrumen, dan pada tahapan aplikasi dengan menggunakan instrumen yang telah valid dan reliabel. Pada tahap uji coba instrumen, diberikan tugas proyek kepada siswa kelas IX SMP dan rubrik penilaian autentik berbasis tugas proyek diberikan kepada guru. Tahap ujicoba instrumen ini dilakukan kepada 31 siswa kelas IX A melalui tugas proyek menggunakan instrumen penilaian autentik yang telah valid dan reliabel.

\section{HASIL DAN PEMBAHASAN}

Penelitian pengembangan yang menghasilkan produk berupa instumen penilaian 
tugas proyek materi statistika SMP mengacu pada model penelitian Borg \& Gall, tetapi dibatasi hanya beberapa tahap saja yaitu: a) tahap pengumpulan informasi; b) tahap perencanaan; c) tahap pengembangan produk; dan d) tahap validasi dan ujicoba. Penjelasan tahapan - tahapan tersebut di jelaskan sebagai berikut:

\section{Tahap Pengumpulan Informasi}

Tahap Pengumpulan Informasi dimulai dengan penentuan materi dan analisis kebutuhan yang akan digunakan dalam pengembangan produk. Sedangkan materi yang dipilih dalam penelitian ini adalah materi statistika. Materi statistika ini diajarkan di kelas IX SMP. Pemilihan materi ini dikarenakan materi ini sangat erat dalam kehidupan sehari -hari sebagai contoh perhitungan jumlah penduduk, perhitungan angka kelulusan ujian nasional tingkat, perhitungan angka kematian tiap tahunnya, perhitungan angka kecelakaan dan sebagainya.

\section{Tahap perencanaan}

Tahap kedua ini terdiri dari pembuatan kisi-kisi instrumen penelitian yang menjadi kriteria penilaian autentik melalui tugas proyek. Kisi-kisi instrumen yang telah selesai dibuat lalu dikembangkan menjadi instrumen penelitian. Instrumen penelitian yang akan digunakan adalah lembar validasi, lembar observasi dan pedoman wawancara. Lembar validasi digunakan untuk mengetahui kelayakan instrumen penilaian autentik melalui tugas proyek dari penilaian ahli pembelajaran dan ahli matematika. Ahli pembelajaran memberi-kan penilaian berdasarkan aspek materi dan pembelajaran, ahli matematika memberikan penilaian berdasarkan aspek materi matematika. Lembar observasi dan pedoman wawancara digunakan untuk mengetahui respon dan tanggapan guru serta siswa mengenai penggunaan instrumen penilaian autentik melalui tugas proyek.

\section{Tahap Pengembangan Produk}

Pada tahap ini, terdapat beberapa langkah-langkah pengerjaan yaitu: 1) Membuat Rancangan Pembelajaran ber-basis Tugas Proyek. 2) Membuat soal untuk tugas proyek yang berhubungan dengan materi statistika SMP kelas IX. 3) Membuat rubrik penilaian tugas proyek. Berikut ini adalah uraian langkahlangkah pengembangan produk :

1) Membuat Rancangan Kegiatan
Pembelajaran berbasis Tugas Proyek

Pada penelitian ini, peniliti memilih materi statistika kelas IX SMP dengan Standart Kompetensi: Melakukan Pengola-han dan Penyajian Data. Dengan Kompetensi Dasar adalah Menyajikan data Menyajikan data dalam bentuk tabel dan diagram batang, garis dan lingkaran. Sedangkan indikator yang ingin dicapai adalah:

1) Mengumpulkan data melalui wawancara.

2) Menyajikan data dalam tabel.

3) Mengolah data.

4) Menyajikan data dalam bentuk diagram batang.

5) Menyajikan data dalam bentuk diagram garis.

6) Menyajikan data dalam bentuk diagram lingkaran.

7) Mempresentasikan penyajian data.

Rancangan pembelajaran berbasis tugas proyek dapat dijabarkan sebagai berikut.

\section{a. Penentuan Pertanyaan Dasar}

Penentuan pertanyaan dasar ini untuk menuntun siswa dalam mengerjakan tugas proyek. Pertanyaan mendasar ini dapat dijadikan langkah awal dalam pengerjaan tugas proyek. Pertanyaan dasar untuk materi statistika SMP adalah sebagai berikut: (1) berapakah rata- rata pengguna bahan jenis bensin, pertalite, pertamax, dan solar antara pukul 14.30-17.00? (2) diantara keempat jenis bahan bakar tersebut, jenis bahan bakar apa yang paling banyak penggunanya? (3) diantara keempat jenis bahan 
bakar tersebut, jenis bahan bakar apa yang paling sedikit penggunanya?

\section{b. Mendesain Perencanaan Proyek (Design a Plan for the Project)}

Kegiatan dalam mendesain proyek ini adalah membuat rancangan perencanaan proyek. Adapun jabarannya sebagai berikut:

1. Membagi kelompok siswa menjadi 6 kelompok yang beranggotakan 5 orang siswa yang heterogen.

2. Menentukan ketua kelompok dan sekretaris di setiap kelompok siswa.

3. Menentukan tempat atau lokasi yang akan digunakan untuk mengambil data. Setiap kelompok akan mengunjungi tempat pengambilan data (pom bensin) sesuai dengan pembagian tempat yang telah ditentukan oleh guru.

Adapun pembagian lokasi observasi adalah sebagai berikut..

\begin{tabular}{|l|l|}
\hline $\begin{array}{c}\text { Nama } \\
\text { Kelompok }\end{array}$ & \multicolumn{1}{|c|}{ Tempat Pengamatan } \\
\hline Kelompok 1 & $\begin{array}{l}\text { Pom bensin Purwodadi } \\
\text { (di Depan Kebun Raya } \\
\text { Purwodadi) }\end{array}$ \\
\hline Kelompok II & Pom Bensin di Purwosari \\
\hline Kelompok III & Pom Bensin Kembang \\
\hline
\end{tabular}

\begin{tabular}{|l|l|}
\hline & Sore, Purwosari \\
\hline Kelompok IV & $\begin{array}{l}\text { Pom Bensin di desa } \\
\text { Sudan }\end{array}$ \\
\hline Kelompok V & $\begin{array}{l}\text { Pom Bensin di desa Bulu } \\
\text { lawang }\end{array}$ \\
\hline
\end{tabular}

4. Menentukan waktu pengerjaan tugas proyek yaitu selama satu bulan, dengan rincian yaitu: pengambilan data selama 2 minggu, mengolahan data selama 1 minggu dan menyusunan laporan selama 1 minggu.

5. Dengan bimbingan guru, setiap kelompok siswa mendiskusikan rancangan kerja untuk menyelesaikan tugas proyek.

6. Setiap kelompok siswa menuliskan hasil diskusi rancangan kerja ke dalam lembar diskusi.

7. Setiap kelompok siswa membuat keseluruhan aktivitas siswa.

\section{e. Menguji Hasil (Assess the Outcome)}

Pada tahap ini, dilakukan penilaian tugas proyek dengan menggunakan rubrik penilaian tugas proyek. Menguji hasil ini dilakukan pada saat siswa mempresentasi-kan hasil kerja tugas proyek.

Tabel 4.4 Rubrik Penilaian Tugas Proyek

\begin{tabular}{|c|c|c|c|c|}
\hline \multirow[t]{2}{*}{ Kategori } & \multicolumn{4}{|c|}{ Skor } \\
\hline & 1 & 2 & 3 & 4 \\
\hline $\begin{array}{l}\text { Desain } \\
\text { Perencanaan } \\
\text { Proyek }\end{array}$ & $\begin{array}{l}\text { Tidak ada } \\
\text { pembuatan } \\
\text { rencana } \\
\text { kegiatan } \\
\text { proyek, } \\
\text { penentuan } \\
\text { tempat } \\
\text { observasi, } \\
\text { pembuatan } \\
\text { rencana } \\
\text { penyelesaian } \\
\text { proyek }\end{array}$ & $\begin{array}{l}\text { Sebagian kecil sudah } \\
\text { ada pembuatan } \\
\text { rencana kegiatan } \\
\text { proyek, penentuan } \\
\text { tempat observasi, } \\
\text { pembuatan rencana } \\
\text { penyelesaian proyek }\end{array}$ & $\begin{array}{l}\text { Sebagian besar sudah } \\
\text { ada pembuatan } \\
\text { rencana kegiatan } \\
\text { proyek, penentuan } \\
\text { tempat observasi, } \\
\text { pembuatan rencana } \\
\text { penyelesaian proyek. }\end{array}$ & $\begin{array}{l}\text { Pembuatan } \\
\text { rencana kegiatan } \\
\text { proyek, } \\
\text { penentuan } \\
\text { tempat } \\
\text { observasi, } \\
\text { pembuatan } \\
\text { rencana } \\
\text { penyelesaian } \\
\text { proyek tersusun } \\
\text { dengan jelas dan } \\
\text { lengkap. }\end{array}$ \\
\hline $\begin{array}{l}\text { Penyusunan } \\
\text { Jadwal } \\
\text { Kegiatan }\end{array}$ & $\begin{array}{l}\text { Tidak ada } \\
\text { sudah ada } \\
\text { penyusunan } \\
\text { jadwal } \\
\text { observasi dan }\end{array}$ & $\begin{array}{l}\text { Sebagian kecil sudah } \\
\text { ada penyusunan } \\
\text { jadwal observasi dan } \\
\text { pengambilan data, } \\
\text { penyusunan alokasi }\end{array}$ & $\begin{array}{l}\text { Sebagian besar sudah } \\
\text { ada penyusunan } \\
\text { jadwal observasi dan } \\
\text { pengambilan data, } \\
\text { penyusunan alokasi }\end{array}$ & $\begin{array}{l}\text { Penyusunan } \\
\text { jadwal kegiatan } \\
\text { observasi dan } \\
\text { pengambilan } \\
\text { data, }\end{array}$ \\
\hline
\end{tabular}




\begin{tabular}{|c|c|c|c|c|}
\hline & $\begin{array}{l}\text { pengambilan } \\
\text { data, } \\
\text { penyusunan } \\
\text { alokasi waktu } \\
\text { kegiatan } \\
\text { observasi dan } \\
\text { pengambilan } \\
\text { serta } \\
\text { pembagian } \\
\text { tugas anggota } \\
\text { kelompok }\end{array}$ & $\begin{array}{l}\text { waktu kegiatan } \\
\text { observasi dan } \\
\text { pengambilan serta } \\
\text { pembagian tugas } \\
\text { anggota kelompok }\end{array}$ & $\begin{array}{l}\text { waktu kegiatan } \\
\text { observasi dan } \\
\text { pengambilan serta } \\
\text { pembagian tugas } \\
\text { anggota kelompok. }\end{array}$ & $\begin{array}{l}\text { penyusunan } \\
\text { alokasi waktu } \\
\text { kegiatan } \\
\text { observasi dan } \\
\text { pengambilan } \\
\text { data, serta } \\
\text { pembagian tugas } \\
\text { anggota } \\
\text { kelompok } \\
\text { tersusun dengan } \\
\text { jelas dan } \\
\text { lengkap }\end{array}$ \\
\hline Pelaksanaan & $\begin{array}{l}\text { Tidak dapat } \\
\text { dapat } \\
\text { melaksanakan } \\
\text { kegiatan tugas } \\
\text { proyek sesuai } \\
\text { dengan } \\
\text { rencana dan } \\
\text { jadwal } \\
\text { kegiatan yang } \\
\text { telah disusun }\end{array}$ & $\begin{array}{l}\text { Sebagaian kecil } \\
\text { sudah dapat } \\
\text { melaksanakan } \\
\text { kegiatan tugas } \\
\text { proyek sesuai } \\
\text { dengan rencana dan } \\
\text { jadwal kegiatan yang } \\
\text { telah disusun }\end{array}$ & $\begin{array}{l}\text { Sebagaian besar } \\
\text { sudah dapat } \\
\text { melaksanakan } \\
\text { kegiatan tugas } \\
\text { proyek sesuai } \\
\text { dengan rencana dan } \\
\text { jadwal kegiatan yang } \\
\text { telah disusun }\end{array}$ & $\begin{array}{l}\text { Dapat } \\
\text { melaksanakan } \\
\text { kegiatan tugas } \\
\text { proyek sesuai } \\
\text { dengan rencana } \\
\text { dan jadwal } \\
\text { kegiatan yang } \\
\text { telah disusun. }\end{array}$ \\
\hline $\begin{array}{l}\text { Pembuatan } \\
\text { Laporan }\end{array}$ & $\begin{array}{l}\text { Tidak dapat } \\
\text { membuat } \\
\text { laporan sesuai } \\
\text { dengan desain } \\
\text { kegiatan } \\
\text { pelaksanaan } \\
\text { tugas proyek } \\
\text { yang telah } \\
\text { disusun. }\end{array}$ & $\begin{array}{l}\text { Sebagian kecil dapat } \\
\text { membuat laporan } \\
\text { sesuai dengan desain } \\
\text { kegiatan pelaksanaan } \\
\text { tugas proyek yang } \\
\text { telah disusun }\end{array}$ & $\begin{array}{l}\text { Sebagian besar dapat } \\
\text { membuat laporan } \\
\text { sesuai dengan desain } \\
\text { kegiatan pelaksanaan } \\
\text { tugas proyek yang } \\
\text { telah disusun. }\end{array}$ & $\begin{array}{l}\text { Dapat membuat } \\
\text { laporan yang } \\
\text { terurut dan } \\
\text { sistematis sesuai } \\
\text { dengan desain } \\
\text { kegiatan } \\
\text { pelaksanaan } \\
\text { tugas proyek } \\
\text { yang telah } \\
\text { disusun. }\end{array}$ \\
\hline $\begin{array}{l}\text { Uji hasil } \\
\text { dengan } \\
\text { pelaksanaan } \\
\text { presentasi }\end{array}$ & $\begin{array}{l}\text { Tidak dapat } \\
\text { mempresentasi } \\
\text { kan hasil } \\
\text { kegiatan dan } \\
\text { tidak dapat } \\
\text { menjawab } \\
\text { pertanyaan } \\
\text { yang diajukan } \\
\text { oleh guru atau } \\
\text { siswa }\end{array}$ & $\begin{array}{l}\text { Sebagian kecil } \\
\text { mempresentasikan } \\
\text { hasil kegiatan dan } \\
\text { dapat menjawab } \\
\text { sebagian kecil } \\
\text { pertanyaan yang } \\
\text { diajukan oleh guru } \\
\text { atau siswa }\end{array}$ & $\begin{array}{l}\text { Sebagian besar } \\
\text { mempresentasikan } \\
\text { hasil kegiatan dengan } \\
\text { lancar dan dapat } \\
\text { menjawab sebagian } \\
\text { besar pertanyaan } \\
\text { yang diajukan oleh } \\
\text { guru atau siswa }\end{array}$ & $\begin{array}{l}\text { Dapat } \\
\text { mempresentasik } \\
\text { an hasil kegiatan } \\
\text { dan dapat } \\
\text { menjawab } \\
\text { semua } \\
\text { pertanyaan yang } \\
\text { diajukan oleh } \\
\text { guru atau siswa }\end{array}$ \\
\hline \multicolumn{3}{|c|}{$\begin{array}{l}\text { Pada tahap ini, dilakukan refleksi pada } \\
\text { akhir proses pembelajaran, terhadap } \\
\text { aktivitas dan hasil proyek yang sudah } \\
\text { dijalankan. }\end{array}$} & \multicolumn{2}{|c|}{$\begin{array}{l}\text { r 3,95 dengan kategori "baik". } \\
\text { Sedangkan hasil validasi ahli materi } \\
\text { ajukkan hasil jumlah skor sebesar } 85 \\
\text { n persentase 85\%, dan rerata skor } \\
\text { r 4 } 55 \text { denoan kateonri "baik" }\end{array}$} \\
\hline \multicolumn{3}{|c|}{$\begin{array}{c}\text { Hasil validasi ahli pembelajaran } \\
\text { menunjukkan hasil jumlah skor sebesar } 78\end{array}$} & \multicolumn{2}{|c|}{$\begin{array}{l}\text { ahli yaitu ahli materi dan ahli } \\
\text { lajaran menunjukkan kategori baik, } \\
\text { ga produk instrumen penilaian }\end{array}$} \\
\hline
\end{tabular}


autentik berbasis tugas proyek layak untuk digunakan dalam pembelajaran matematika pada materi statistika SMP.

\section{Tahap Ujicoba}

\section{a) Hasil Observasi}

Observasi dilakukan untuk mengetahui respon guru matematika dan siswa SMP Al - Inayah kelas IX dalam penggunaan instrumen penilaian autentik berbasis tugas proyek. Berikut ini adalah data hasil observasi:

1) Pada waktu ujicoba dilaksanakan, siswa terlihat antusias. Hal ini dikarenakan membuat tugas proyek merupakan pengalaman pertama bagi mereka. Berikut ini adalah gambar siswa ketika berkelompok untuk mendiskusikan rencana pengerjaan tugas proyek.

2) Dalam menyusun jadwal kegiatan, siswa masih kelihatan bingung, karena setiapanggota kelompok mempunyai pendapat - pendapat sendiri - sendiri. Tetapi dengan bantuan guru, akhirnya siswa dapat menyatukan pendapatnya. Berikut adalah gambar siswa pada saat berkelompok.

3) Saat pengambilan data ke tempat- tempat yang telah ditentukan, siswa tampak kesulitan. Mereka masih terlihat malu malu dan takut untuk bertanya tentang informasi dalam penyusunan tugas proyek. Hal ini terlihat dari laporan siswa pada saat bimbingan dengan guru. Sehingga mereka harus bolak - balik ke tempat pengambilan data. Karena pada saat tibadi lokasi mereka takut bertanya sehingga tidak mendapatkan informasi data untuk mengerjakan tugas proyek.

4) Pada saat menyusun laporan, siswa terlihat antusias ketika mendapat arahan dan bimbingan dari guru. Siswa yang semula tidak dapat menulis dan menyusun laporan, akhirnya dapat menyusun laporan berdasarkan kegiatan pada saat pengambilan data.

5) Pada saat pelaksanaan uji hasil melalui presentasi, siswa dapat mempersentasikan dengan lancar. Sebanyak 21 siswa atau sekitar $70 \%$ siswa dapat menjawab pertanyaan dari guru yang berkaitan dengan tugas proyek. Hal ini membuktikan bahwa dengan pengalaman yang nyata, siswa akan lebih memahami konsep statistika dalam kehidupan sehari - hari.

6) Dengan adanya tugas proyek, siswa terlihat antusias karena pembelajaran tidak hanya di dalam kelas, tetapi mereka belajar ke tempat -tempat baru untuk mendapatkan informasi data yang berkaitan dengan tugas proyek. Selain itu soal tugas proyek yang diberikan berbeda disetiap kelompoknya dapat memperkaya ilmu statistik.

\section{b) Hasil Wawancara dengan Guru}

Wawancara dengan guru dilakukan untuk mengetahui respon guru terhadap instrumen penilaian autentik berbasis tugas proyek. Adapun hasil wawancara adalah sebagai berikut:

1) Langkah - langkah pembelajaran yang tertuang dalam RPP sudah urutdan sistematis sehingga memudahkan guru dalam melaksanakan pembelajaran.

2) Soal tugas proyek bervariasi. Hal ini terlihat ketika setiap kelompok mendapat soal yang berbeda.

3) Selama ini materi statistik diberikan secara menoton atau hanya dengan pemberian tugas dikelas, tetapi dengan adanya tugas proyek, siswa mendapat pengalaman baru.

4) Dengan adanya tugas proyek, guru lebih mudah dalam menilai secara autentik tentang pemahaman siswa. Siswa yang tidak bekerjasama dengan kelompoknya pasti akan kelihatan.

5) Rubrik yang dikembangkan menggambarkan tahapan-tahapan dalam pelaksanaan tugas proyek. Tentunya hal ini memudahkan guru dalam menilai hasil kerja siswa.

6) Pedoman penskoran dalam rubrik terarah dan terukur dengan jelas.

c) Hasil Wawancara dengan Siswa

Wawancara yang dilakukan tidak hanya dengan guru, melainkan dengan siswa. Hal ini dilakukan untuk mengetahui respon siswa tentang pelaksanaan tugas proyek. Wawancara ini dilakukan terhadap 
10 orang siswa atau $30 \%$ dari jumlah siswa. Berikut ini adalah hasil wawancara dengan siswa:

1) Siswa NMR, DWT, STH, DAR mengaku sangat senang dengan adanya tugas proyek. Karena dapat berkeliling ke pom bensin untuk mendapatkan data. Sehingga tudak bosan belajar di kelas saja.

2) Siswa RF berpendapat bahwa dengan adanya tugas proyek siswa dapat menulis laporan. Tertanya tidak hanya pelajaran Bahasa Indonesiasaja, materi matematika juga dapat dijadikan laporan.

3) Siswa BCF dan AW memberi saran untuk pembagian kelompok seharusnya disesuaikan tempat tinggal dan tempat pengambilan data. Kendala jarak rumah dalam satu kelompok membuat angota kelompok yang rumahnya jauh tidak aktif dalam mengerjakan tugas proyek.

4) Siswa AT berpendapat pembelajaran matematika menjadi menarik dengan adanya tugas proyek. AT yang biasanya pemalu menjadi aktif bertanya.

5) Siswa TRE dan FG lebih memahami materi statistik melalui tugas proyek, karena siswa dapat belajar secara langsung tentang kegunaan materi statistik dalam kehidupan sehari hari.

\section{SIMPULAN}

Penelitian pengembangan yang menghasilkan produk berupa instumen penilaian tugas proyek materi statistika SMP mengacu pada model penelitian Borg \& Gall, tetapi dibatasi hanya beberapa tahap saja yaitu: a) tahap pengumpulan informasi; b) tahap perencanaan; c) tahap pengembangan produk; dan d) tahap validasi dan ujicoba.Hasil validasi ahli pembelajaran menunjukkan hasil jumlah skor sebesar 78 dengan persentase $78 \%$, dan rerata skor sebesar 3,95 dengan kategori "baik". Sedangkan Hasil validasi ahli materi menunjukkan hasil jumlah skor sebesar 85 dengan persentase $85 \%$, dan rerata skor sebesar 4,25 dengan kategori "baik". Berdasarkan hasil validasi dari kedua ahli yaitu ahli materi dan ahli pembelajaran menunjukkan kategori baik, sehingga produk instrumen penilaian autentik berbasis tugas proyek layak untuk digunakan dalam pembelajaran matematika pada materi statistika SMP

\section{DAFTAR PUSTAKA}

Arikunto S. 2006. Prosedur Penelitian Suatu Pendekatan Praktik. Jakarta: Rineka Cipta

Borg,W.R \& Gall,M.G (1989), Educational Research: An Introduction (5th ed.). New York:Longman

Burton, K. 2011. A Framework for Determining The Authenticity of

Assessment Tasks: Applied to an Example In Law . Journal of Learning Design.

Hamzah B. Uno dan Satria Koni. 2012. Assessment Pembelajaran. Jakarta: Bumi Aksara

Havnes, A and McDowell, L. 2008. Balancing Dilemmas in Assessment and Learning in Contemporary Education. New York: Master e Book.

Mueller, J. 2008. Authentic Assessment Toolbox. North Central Collegehttp:/ /www.noctrl.edu/,Naperville,http://jonath an.mueller.faculty.noctrl.edu/toolbox/ind ex.-htm. Diunduh 23 Februari 2015.

Permendiknas Nomor 20 Tahun 2007 Tentang Standar Penilaian Pendidikan. 